\title{
ДИНАМІКА ПОКАЗНИКІВ АНТИОКСИДАНТНОї СИСТЕМИ ТА ПЕРЕКИСНОГО ОКИСНЕННЯ ЛІПІДІВ У ВАГІТНИХ З ДИСФУНКЦІЄЮ ПЛАЦЕНТИ ПІД ВПЛИВОМ КОМПЛЕКСНОї ТЕРАПIÏ
}

\author{
ФВ. В. Овчарук, А. В. Бойчук, О. І. Хлібовська
}

ДВНЗ «Тернопільський державний медичний університет імені І. Я. Горбачевського МОЗ України»

\begin{abstract}
РЕзюМЕ. Мета - вивчити вплив комплексного лікування дисфункції̈ плаценти у вагітних на зміни показників перекисного окиснення ліпідів та антиоксидантної системи.

Матеріал і методи. Проведено порівняльний клініко-статистичний аналіз показників перекисного окиснення ліпідів та стану антиоксидантної системи. Залежно від методу лікування вагітні були поділені на дві групи: І група 30 вагітних, які отримували загальноприйняту терапію, II група - 30 вагітних, які отримували комплексну терапію. Контрольну групу склали 30 жінок з фізіологічним перебігом вагітності. Дані було оброблено статистично за допомогою програм Microsoft Exel 2013 із використанням тесту хі-квадрат $\left(\chi^{2}\right)$, критерію Стьюдента (t), достовірності розходжень між показниками (р).

Результати. Проведено аналіз кінцевих продуктів перекисного окиснення ліпідів (малоновий діальдегід, дієнові кон'югати) та антиоксидантної системи (вітамін А, вітамін Е, супероксиддисмутаза, каталаза) у групах залежно від методу лікування плацентарної дисфункції та в порівнянні з контрольною групою. Порівняльна характеристика рівня кінцевих продуктів ПОЛ свідчила про значне зниження рівнів МДА і ДК в ІІ групі, порівняно з І групою вагітних. Було встановлено достовірне підвищення рівня вітаміну А в II групі, порівняно з I групою, в 1,14 раза (р<0,05). Відмічено підвищення концентрації вітаміну E в II дослідній групі в 1,25 раза, порівняно з аналогічними даними в I групі, що не отримувала запропоновану терапію, що пояснюється його високим вихідним рівнем. Нами доведена здатність L-аргініну та L-карнітину стимулювати як ферментативні, так і неферментативні ланцюги AOC.

Висновки. 1. Одним із факторів патогенезу плацентарної дисфункції можна вважати недостатність антиоксидантного захисту в організмі вагітних, що призводить до підвищення рівня продуктів перекисного окиснення ліпідів у крові і тканинах. Дисбаланс у системі перекисного окиснення ліпідів та антиоксидантної системи захисту призводить до патологічних процесів у фетоплацентарному комплексі.

2. Призначення комплексної терапії з включенням L-карнітину та L-аргініну сприяє нормалізації показників перекисного окиснення ліпідів та антиоксидантного захисту.

КлючОВІ СлОВА: вагітні; дисфункція плаценти; малоновий діальдегід; дрієнові кон'югати; супероксиддисмутаза; вітамін А; вітамін Е; каталаза.
\end{abstract}

Вступ. Охорона здоров'я матері і дитини $\epsilon$ пріоритетним напрямком сучасної медицини. Проблема дисфункції плаценти при вагітності $€$ важливою проблемою сучасного акушерства, тому що $\epsilon$ причиною перинатальної захворюваності та смертності $[1,3,9,10]$. Особливо актуальною ця проблема $\epsilon$ при ускладненні дисфункції плаценти затримкою росту плода $[4,5,6]$. Активація процесів ПОЛ $є$ одним з ключових механізмів пошкодження плаценти. Вивчення показників оксидативного стресу, що виникає внаслідок дисбалансу між ПОЛ і АОЗ, дає змогу розкрити патогенез патологічних процесів, оцінити ступінь ризику їх виникнення, прогнозувати особливості перебігу захворювання. Усунення оксидативного стресу сприяє підвищенню ефективності лікувально-реабілітаційних заходів $[5,8]$. Як було доведено, у першому триместрі вагітні, в яких діагностовано дисфункцію плаценти, мали серйозні порушення в системі ПОЛ. Тому актуальним $\epsilon$ пошук методів ранньої діагностики, патогенетичних механізмів розвитку плацентарної недостатності та розробка адекватних патогенетично обґрунтованих методів лікування. Дисбаланс в системі пере- кисного окиснення ліпідів та антиоксидантної системи захисту призводить до цілого ряду патологічних процесів, зокрема і в біосистемі «матиплацента-плід» $[2,3]$. Водночас у жінок із плацентарною дисфункцією, імовірно, гіпоксія, що розвивається, може зумовлювати інтенсифікацію ПОЛ у тканинах і виділення продуктів вільнорадикального окиснення в кров'яне русло $[2,3]$.

Згідно з літературними даними, фізіологічний перебіг вагітності супроводжується вираженим окиснювальним стресом внаслідок дисбалансу роботи систем регуляції процесів вільнорадикального окиснення ліпідів та антиоксидантного захисту, що сприяє активації систем утворення активних форм кисню $[2,3]$.

Мета - вивчити вплив комплексного лікування дисфункціїі плаценти у вагітних на зміни показників перекисного окиснення ліпідів та антиоксидантної системи.

Матеріал та методи дослідження. Нами проведено обстеження стану перекисного окиснення ліпідів та антиоксидантної системи у вагітних з дисфункцією плаценти. Залежно від методу лікування вагітні були поділені на дві групи: I гру- 
Огляди літератури, оригінальні дослідження, погляд на проблему

па - 30 вагітних, які отримували загальноприйняту терапію та II - 30 вагітних, які отримували комплексну запропоновану терапію. Контрольну групу склали 30 вагітних з фізіологічним перебігом вагітності. Стан перекисного окиснення ліпідів оцінювали за показниками початкових, проміжних та кінцевих продуктів перекисного окиснення ліпідів та стану антиоксидантної системи. Стан перекисного окиснення ліпідів у вагітних, оцінювали за вмістом у плазмі крові первинних продуктів перекисного окиснення ліпідів - дієнових кон'югатів (ДК) і вторинних - малонового діальдегіду (МДА), які визначали за методиками І. Д. Стальної, Т. Г. Гарішвілі (1977) та І. Д. Стальної, М. Г. Гарішвілі (1997). Активність ферментативної ланки антиоксидантної системи захисту визначали за вмістом каталази та супероксиддисмутази (СОД) з використанням загальноприйнятих методик.

Неферментативний ланцюг антиоксидантної системи захисту оцінювали за вмістом в сироватці крові вітаміну А та вітаміну Е. Обстеження проводили до лікування та після лікування. Вагітні II групи з плацентарною дисфункцією отримували комплексну терапію: тіворель 100 мл внутрішньовенно, з переходом на пероральний прийом аргініну гідрохлориду в дозі 5 мл 3-4 рази на добу і розчин левокарнітину («Алміба») 10 мл (100 мг/мл левокарнітину).
Результати й обговорення. Після проведення у вагітних з плацентарною дисфункцією комплексної терапії були проаналізовані аналогічні показники в обстежуваних групах вагітних. Порівняльна характеристика рівня кінцевих продуктів ПОЛ свідчила про значне зниження рівнів МДА і ДК в II групі, порівняно з I групою вагітних. Та, у II групі концентрація МДА була достовірно нижчою, ніжуІ групі, й становила $(10,10 \pm 0,23)$ мкмоль/л проти $(14,62 \pm 0,32)$ мкмоль/л в I групі $(p<0,001)$. Проте цей показник у II групі залишився вищим, ніж у контрольній групі- $(8,26 \pm 0,12)$ мкмоль/л $(p<0,05)$, що пов'язано з більш вираженим вихідним рівнем порушень в процесах ПОЛ. Рівень ДК залишився достовірно вищим в I групі - $(4,38 \pm 0,06)$ мкмоль/л, порівняно як з ІІ групою - $(2,51 \pm 0,07)$ мкмоль/л, так і з контролем - $(2,65 \pm 0,10)$ мкмоль/л $(p<0,001)$. Достовірної різниці між показниками II і контрольної групи не відмічено. Ми проаналізували стан антиоксидантної системи у вагітних обстежуваних груп у третьому триместрі. Як і в I триместрі, вміст ретинолу не виходив за межі фізіологічних коливань у всіх групах, хоча було встановлено достовірне підвищення рівня вітаміну А в ІІ групі, порівняно з I групою. Відмічено підвищення концентрації вітаміну Е в II дослідній групі після лікування в 1,48 раза, а в I групі - в 1,18 раза, вагітні отримували загальноприйняту терапію (табл. 1).

Таблиця 1. Порівняльна характеристика стану ПОЛ і антиоксидантної системи вагітних жінок в третьому триместрі вагітності після лікування $(\mathrm{M} \pm \mathrm{m})$

\begin{tabular}{|c|c|c|c|c|c|}
\hline Показник & $\begin{array}{c}\text { Статистичний } \\
\text { показник }\end{array}$ & До лікування & Група I, n=30 & Група II, n=30 & $\begin{array}{c}\text { Контрольна група, } \\
\text { n=30 }\end{array}$ \\
\hline \multicolumn{6}{|c|}{ Кінцеві продукти ПОЛ } \\
\hline \multirow{2}{*}{$\begin{array}{l}\text { МДА, } \\
\text { мКмоль/л }\end{array}$} & $M \pm m$ & $16,39 \pm 0,32$ & $14,62 \pm 0,29 *$ & $10,10 \pm 0,23 * *$ & $8,26 \pm 0,12$ \\
\hline & $p$ & & $<0,001$ & $<0,05$ & - \\
\hline \multirow{2}{*}{$\begin{array}{l}\text { ДК, } \\
\text { мКмоль/л }\end{array}$} & $M \pm m$ & $6,09 \pm 0,11$ & $4,38 \pm 0,06^{*}$ & $2,51 \pm 0,07 * *$ & $2,65 \pm 0,10$ \\
\hline & $p$ & & $<0,001$ & $<0,001$ & - \\
\hline \multicolumn{6}{|c|}{ Антиоксидантна система } \\
\hline \multirow{2}{*}{$\begin{array}{l}\text { Вітамін } \\
\text { мкмоль/л }\end{array}$} & $M \pm m$ & $2,12 \pm 0,05$ & $2,27 \pm 0,07$ & $2,50 \pm 0,07 * *$ & $2,35 \pm 0,05$ \\
\hline & $p$ & & - & $<0,05$ & - \\
\hline \multirow{2}{*}{$\begin{array}{l}\text { Вітамін Е, } \\
\text { мкмоль/л }\end{array}$} & $M \pm m$ & $5,67 \pm 0,09$ & $6,74 \pm 0,23$ & $8,46 \pm 0,15^{* *}$ & $8,20 \pm 0,14$ \\
\hline & $\mathrm{p}$ & & - & $<0,01$ & - \\
\hline \multirow{2}{*}{$\begin{array}{l}\text { СОД, Од/мг } \\
\text { Білка }\end{array}$} & $\mathrm{M} \pm \mathrm{m}$ & $2,33 \pm 0,05$ & $4,57 \pm 0,19 *$ & $7,72 \pm 0,19 * *$ & $5,69 \pm 0,11$ \\
\hline & $\mathrm{P}$ & & $<0,05$ & $\begin{array}{l}<0,01 \\
<0,001 \\
\end{array}$ & - \\
\hline \multirow{2}{*}{$\begin{array}{l}\text { Каталаза, } \\
\text { мкат/л }\end{array}$} & $M \pm m$ & $10,23 \pm 0,25$ & $14,33 \pm 0,22 *$ & $18,67 \pm 0,19 * *$ & $23,28 \pm 0,11$ \\
\hline & $\mathrm{p}$ & & $<0,001$ & $\begin{array}{l}<0,01 \\
<0,05\end{array}$ & - \\
\hline
\end{tabular}

Примітки: 1.* - різниця достовірна в порівнянні з контролем;

2.** - різниця достовірна між групами I i II. 
Огляди літератури, оригінальні дослідження, погляд на проблему

Аналізуючи зміни в ферментативному ланцюзі АОС необхідно зазначити, що найбільше змінилась активність СОД. Так, концентрація СОД у вагітних II групи була достовірно вищою, ніж в І групі: відповідно $(7,72 \pm 0,19)$ Од/мг білка проти $(4,57 \pm 0,19)$ Од/мг білка $(p<0,001)$. Спостерігали також достовірну різницю між показниками II і контрольної груп $(p<0,01)$. При оцінці рівня каталази відмічено ї̈ достовірне підвищення в II групі ((18,67士

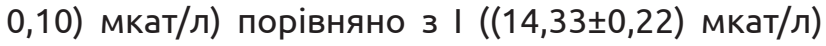
$(p<0,05)$. У ході дослідження виявлено посилене використання як вітаміну A, так і вітаміну E, у процесах перекисного окиснення ліпідів, про що свідчить зниження їх рівнів в основній групі в 1,4 i 1,5 раза відповідно, порівняно з контрольною групою. Після проведення комплексної терапії у обстежуваних другої групи мало місце зростання рівнів вітамінів групи A, E.

Аналізуючи отримані дані можна зробити висновок, що дизрегуляція ферментів першої ланки антиоксидантного захисту призводить до накопичення різних форм активних кисневих метаболітів, які на молекулярному рівні $\epsilon$ ланками патогенезу дисфункції плаценти. Проте активація процесів перекисного окиснення ліпідів впливає не тільки на молекулярний механізм клітинного пошкодження, а й направлена на формування компенсаторно-пристосувальних реакцій. Від ступеня вираженості цих порушень буде залежати результат впливу окиснювального стресу на рівні клітини чи цілого організму. Залежно від вираженості цих змін порушення в фетоплацентарному комплексі перебувають у фазі компенсації чи декомпенсації. Проаналізувавши результати прове-

\section{ЛІТЕРАТУРА}

1. Аналіз частоти та причини затримки росту плода, особливостей перебігу вагітності і пологів / В. П. Присяжнюк, О. О. Кулик, О. М. Хвостик, С. Г. Кочко // Медикосоціальні проблеми сім'ї. - 2006. - Т. 11, № 3. - С. 56-59.

2. Застосування L-аргініну в комплексній терапії фетоплацентарної дисфункції / А. В. Бойчук, А. Ю. Франчук, І. М. Нікітіна [та ін.] // Актуальні питання педіатрії, акушерства та гінекології - 2011. - № 1. - С. 81-85.

3. Лоскутова Т. А. Характеристика обмена и перекисного окиснения липидов у беременных с преэклампсией и акушерскими и перинатальными осложнениями / Т. А. Лоскутова // Український Морфологічний альманах. - 2013. - Т. 11, № 1. - С. 117-119.

4. Маркін Л. Б. Діагностично-профілактичні заходи при затримці функціонального диференціювання плаценти / Л. Б. Маркін, О. О. Михайлів // Педіатрія, акушерство та гінекологія. - 2008. - № 5. - С. 63-67.

5. Особливості плацентарного кровообігу в жінок із затримкою росту плода/ В. В. Овчарук, А. В. Бойчук, О. І. Хлібовська [та ін.] // Актуальні питання педіатрії, акушерства та гінекології. - 2015. - № 2. - С. 137-139. дених досліджень ми прийшли до висновку, що в групі жінок з дисфункцією плаценти, вагітність у яких велась традиційно, збереглись всі негативні тенденції, виявлені в I триместрі. При аналізі процесів ПОЛ встановлена здатність L-аргініну та L-карнітину знижувати його інтенсивність за рахунок прямої антиоксидантної дії, що дозволяє інгібувати ПОЛ в мембранах клітин органів-мішеней, у результаті чого зменшується концентрація основних продуктів перекисного окиснення ліпідів, припиняється розгалуження ланцюгів вільнорадикального окиснення, утримується про- і антиоксидантна рівновага в межах, близьких до оптимальних. Нами доведена здатність L-аргініну стимулювати як ферментативні, так і неферментативні ланки антиоксидантної системи.

Висновки. 1. Одним із факторів патогенезу плацентарної дисфункції можна вважати недостатність антиоксидантного захисту в організмі вагітних, що призводить до підвищення рівня продуктів перекисного окиснення ліпідів у крові й тканинах. Дисбаланс у системі перекисного окиснення ліпідів та антиоксидантної системи захисту призводить до патологічних процесів у фетоплацентарному комплексі.

2. Призначення комплексної терапії з включенням L-карнітину та L-аргініну сприяє нормалізації показників перекисного окиснення ліпідів та антиоксидантного захисту.

Перспективи подальших досліджень полягають у подальшій розробці диференційованого підходу до лікування плацентарної дисфункції у вагітних, враховуючи дисбаланс у системі перекисного окиснення ліпідів та антиоксидантного захисту.

6. Плацентарная недостаточность. Патогенез. Прогнозирование. Диагностика. Профилактика. Акушерская тактика : монография / А. Н. Стрижаков, И. С. Липатов, Ю. В. Тезиков. - Самара : ООО «Офорт», 2014. 239 C.

7. Barker D. J. Placental programming of chronic diseases, cancer and lifespan: a review / D. J. Barker, K. L. Thornburg // Placenta. - 2013. - Vol. 34, No. 10. - P. 841-845.

8. Gardosi J. Preventing stillbirths through improved antenatalrecognition of pregnancies at risk due to fetal growth restriction / J. Gardosi // Public Health. - 2014. Vol. 128, No. 8. - P. 698-702.

9. Lee W. Jennifer Future applications of antioxidants in premature infants / Jennifer W. Lee, Jonathan M. Davis // Curr. Opin. Pediatr. Author manuscript. -2011. - No. 23 (2). P. 161-166.

10. Mierzynski R. Intra-uterine growth retardation as a risk factor of postnatal metabolic disorders / R. Mierzynski // Curr. Pharm. Biotechnol. - 2016. - Vol. 17, No. 7. P. 587-596. 
Огляди літератури, оригінальні дослідження, погляд на проблему REFERENCES

1. Prysiazhniuk, V.P., Kulyk, O.O., Khvostyk, O.M. \& Kochko, S.H. (2006). Analiz chastoty ta prychyny zatrymky rostu ploda, osoblyvostei perebihu vahitnosti i polohiv [Analysis of the frequency and causes of fetal growth retardation, features of the course of pregnancy and childbirth]. Medyko-sotsialni problemy simi - Medical and Social Problems of the Family, (11), 3, 56-59 [in Ukrainian].

2. Boichuk, A.V., Franchuk, A.Yu., Nikitina, I.M., Hrinkevych, T.M., Behosh, B.M., Khlibovska, O.I. \& Shadrina, V.S. (2011). Zastosuvannia L-arhininu $v$ kompleksnii terapii fetoplatsentarnoi dysfunktsii [Application of L-arginin in complex therapy of fetoplacentary dysfunction]. Aktualni pytannia pediatrii, akusherstva ta hinekolohii-Actual Issues of Pediatrics, Obstetrics and Gynecology, 1, 81-85 [in Ukrainian].

3. Loskutova, T.A. (2013). Kharakteristika obmena i perekisnogo okisleniya lipidov u beremennykh s preeklampsiyey i akusherskimi i perinatalnymi oslozhneniyami [Characteristics of lipid metabolism and peroxidation in pregnant women with preeclampsia and obstetric and perinatal complications]. Ukrainskyi morfolohichnyi almanakh - Ukrainian Morphological Almanac, (11), 1, 117-119 [in Russian].

4. Markin, L.B. \& Mykhailiv, O.O. (2008). Diahnostychnoprofilaktychni zakhody pry zatrymtsi funktsionalnoho dyferentsiiuvannia platsenty [Diagnostic and prophylactic measures with delay of functional differentiation of the placenta]. Pediatriia, akusherstvo ta hinekolohiia - Pediatrics, Obstetrics and Gynecology, 5, 63-67 [in Ukrainian].

5. Ovcharuk, V.V., Boichuk, A.V. Khlibovska, O.I. \& Dzhyvak, V.H. (2015). Osoblyvosti platsentarnoho krovoobihu $v$ zhinok iz zatrymkoiu rostu ploda [Features of placental circulation in women with fetal growth retardation]. Aktualni pytannia pediatrii, akusherstva ta hinekolohii - Actual Issues of Pediatrics, Obstetrics and Gynecology, 2, 137-139 [in Ukrainian].

6. Strizhakov, A.N., Lipatov, I.S. \& Tezikov, Yu.V. (2014). Platsentarnaya nedostatochnost: Patogenez. Prognozirovaniye. Diagnostika. Profilaktika. Akusherskaya taktika: monografiya [Placental insufficiency: Pathogenesis. Forecasting. Diagnostics. Prevention. Obstetrical tactics: monograph]. Samara: OOO "Ofort" [in Russian].

7. Barker, D.J. \& Thornburg, K.L. (2013). Placental programming of chronic diseases, cancer and lifespan: a review. Placenta, (34), 10, 841-845.

8. Gardosi, J., Giddings, S., Buller, S., Southam, M. \& Williams, M. (2014). Preventing stillbirths through improved antenatalrecognition of pregnancies at risk due to fetal growth restriction. Public Health, (128), 8, 698-702.

9. Lee W. Jennifer \& Davis M. Jonathan (2011). Future applications of antioxidants in premature infants. Curr. Opin. Pediatr. Author Manuscript., 23 (2), 161-166.

10. Mierzynski, R., Dluski, D., Darmochwal-Kolarz, D., Poniedziałek-Czajkowska, E., Leszczynska-Gorzelak, B., Kimber-Trojnar, Z. ... Agnieszka-Wankowicz (2016). Intrauterine growth retardation as a risk factor of postnatal metabolic disorders. Curr. Pharm. Biotechnol., (17), 7, 587-596.

\title{
ДИНАМИКА ПОКАЗАТЕЛЕЙ АНТИОКСИДАНТНОЙ СИСТЕМЫ И ПЕРЕКИСНОГО ОКИСЛЕНИЯ ЛИПИДОВ У БЕРЕМЕННЫХ С ДИСФУНКЦИЕЙ ПЛАЦЕНТЫ ПОД ВЛИЯНИЕМ КОМПЛЕКСНОЙ ТЕРАПИИ
}

\author{
○ В. В.Овчарук, А. В. Бойчук, О. И. Хлибовская \\ ДВНз «Тернопольский государственный медицинский университет имени И. Я. Горбачевского \\ МЗ Украины»
}

РЕЗЮМЕ. Цель - изучить влияние комплексного лечения дисфункции плаценты у беременных на изменение показателей перекисного окисления липидов и антиоксидантной системы.

Материал и методы. Проведен сравнительный клинико-статистический анализ показателей перекисного окисления липидов и состояния антиоксидантной системы. В зависимости от метода лечения беременные были поделены на две группы; I группа - 30 беременных, получавших общепринятую терапию, II группа - 30 беременных, получавших комплексную терапию с использованием карнитина и L-аргинина. Контрольную группу составили 30 беременных с физиологическим течением беременности. Данные были обработаны статистически с помощью программ Microsoft Exel 2013 с использованием критерия Стьюдента (t), достоверности различий между показателями (р).

Результаты. Проведен анализ конечнихпродуктов перекисного окисления липидов (малонового диальдегида, диеновых конъюгатов) и антиоксидантной системы защиты (витамин А, витамин Е, супероксиддисмутаза, каталаза) в группах в зависимости от метода лечения плацентарной дисфункции и по сравнению с контрольной группой. Сравнительная характеристика уровня конечних продуктов ПОЛ свидетельствовала о значительном снижении уровня МДА и ДК во ІІ группе, по сравнению с I группой беременных. Было установлено достоверное повышение уровня супероксиддисмутазы во II группе, по сравнению с I группой, в 1,14 раза $(p<0,05)$. Отмечено повышение концентрации каталазы во II опытной группе в 1,25 раза, по сравнению с аналогичными данными в первой группе, не получавшей разработанный комплекс терапии. Комплексное использование карнитина и L-аргинина в качестве дополнительного лечения дисфункции плаценты обладает способностю стимулировать как ферментативные, так и неферментативные цепи АОС и достоверно снижать активность перекисного окисления липидов при дисфункции плаценты как универсального механизма повреждения ендотелия сосудов плацентарного ложа. 
Огляди літератури, оригінальні дослідження, погляд на проблему

Выводы. 1. Одним из факторов патогенеза плацентарной дисфункции можно считать недостаточность антиоксидантной защиты в организме беременных, что ведет к повышению уровня продуктов перекисного окисления липидов в крови и тканях. Дисбаланс в системе перекисного окисления липидов и антиоксидантной системы защиты ведет к патологическим процессам в фетоплацентарном комплексе.

2. Назначение комплексной терапии с включением L-карнитина и L-аргинина способствует нормализации показателей перекисного окисления липидов и антиоксидантной защиты.

КЛюЧЕВЫЕ СЛОВА: беременные; дисфункция плаценты; малоновый диальдегид; диеновые конъюгаты; супероксиддисмутаза; витамин А; витамин Е; каталаза.

\title{
DYNAMICS OF INDICATORS OF ANTIOXIDANT SYSTEM AND LIPID PEROXIDATION IN PREGNANT WOMEN WITH PLACENTAL DYSFUNCTION UNDER THE INFLUENCE OF COMPLEX THERAPY
}

\author{
OV. V. Ovcharuk, A. V. Boychuk, O. I. Khlibovskaya \\ I. Horbachevsky Ternopil State Medical University
}

SUMMARY. The aim of the study to learn the effect of complex treatment of placental dysfunction in pregnant women on changes in lipid peroxidation and antioxidant system.

Materials and Methods. A comparative clinical and statistical analysis of lipid peroxidation and antioxidant system status has been carried out. Depending on the method of treatment, pregnant women were divided into two groups: group 1 - 30 pregnant women received standard therapy, group 2 - 30 pregnant women received complex therapy. The control group consisted of 30 women with a physiological course of pregnancy. The data was statistically processed using Microsoft Exel 2013 programs using the Chi-square test $\left(\chi^{2}\right)$, Student's criterion ( $t$ ), and the reliability of the differences between metrics ( $p)$.

Results. The analysis of end products of lipid peroxidation oxidation (malonic dialdehyde, diene conjugates) and antioxidant system (vitamin $A$, vitamin $E$, superoxide dismutase, catalase) in groups depending on the method of treatment of placental dysfunction and in comparison with the control group. The comparative characterization of the level of end products of the LP indicated a significant decrease in the level of MDA and DC in group 1 compared with the group 1 of pregnant women. A significant increase in the level of vitamin A in the group 2 compared with the group 1 was found to be 1.14 times, $(p<0.05)$. Increased concentration of vitamin $E$ in the group 2 of patients was 1.25 times compared with similar data in group 1, which did not receive the proposed therapy, which is explained by its high initial level. The proven ability of L-arginine and L-carnitine to be stimulated as enzymatic, yes and non-enzymatic chains of AOS.

Conclusions 1 . One of the factors of the pathogenesis of placental dysfunction deficiency of antioxidant defense in pregnant women can be considered leading to an increase in the level of lipid peroxidation in blood and tissues. Imbalance in the system of lipid peroxidation and antioxidant defense system leads to pathological processes in the fetoplacental complex.

2. The purpose of complex therapy with the inclusion of L-carnitine and L-arginine promotes the normalization of indicators of lipid peroxidation and antioxidant protection.

KEY WORDS: pregnant; placenta dysfunction; malodialdeleg; drainage conjugates; superoxide dismutase; vitamin A; vitamin E; catalase.

Отримано 19.07.2017 